\title{
Case Law in Germany: The Significance of Seuffert's Archiv
}

\author{
CLARA GÜNZL
}

Common law and Civil law can be regarded as contrary legal systems: their two main characteristics are usually named as, respectively, case law developed from concrete judicial decisions and statutory law interpreted by legal scholars. The concept of case law seems not to fit the Continental Civil law system. Though research stresses a recent convergence of Common law and Civil law systems, these different legal cultures are often said to derive from the nineteenth century. ${ }^{1}$ The clear English appeal stages made it useful for the higher courts' guidelines and decisions to be followed strictly, whereas the multiple judiciaries in the German Confederation opened the way for a discussion among scholars as long as Roman law was applicable.

However, in 1968 the legal historian John Dawson profoundly questioned the differentiation by entitling events between 1800 and 1945 as 'Germany's Case-Law Revolution'. ' His study The Oracles of the Law compared reasoned decisions in different legal cultures, looking at England, Rome, France and Germany. He examined 'the nature and extent of the contribution that case law has made' to them. ${ }^{3}$ Naming published reasoned decisions as an 'important symptom', he observed a 'steady rise in the prestige and influence of the German judiciary'

${ }^{1}$ M. Reimann, 'Die Erosion der klassischen Formen - Rechtskulturelle Wandlungen des Civil Law und Common Law im Europa des 19. und 20. Jahrhunderts', Zeitschrift für Neuere Rechtsgeschichte, 28 (2006), 209-34, at 216. If one thinks of these idealised concepts, the nineteenth century approaches them as closely as possible in reality; ibid., 233.

I would like to thank the editors for the opportunity to contribute to the volume and the helpful comments and rephrasing propositions which I gladly adopted. All translations are my own.

2 J. P. Dawson, The Oracles of the Law (Ann Arbor, MI, 1968), 432.

3 Ibid., xi. 
throughout the nineteenth century to the time of his writing. ${ }^{4}$ To rephrase it, Dawson attested a growing importance of the judiciary associated with a more dominant role of case law as a fundamental change.

The following paper examines this theory for the mid-nineteenth century by taking an influential collection as an example. From 1847 onwards 'Seuffert's Archiv' reprinted numerous selected decisions of the highest regional courts for a nationwide readership. When talking about case law, this article is focused on the concept of precedents that determine the outcome of future similar cases. I explore the tension in German law between the clear doctrine that prior decisions do not have a legally binding effect and the evidence from practice that prior cases influenced future decisions. The examination of this famous nineteenthcentury collection provides help in understanding historical aspects of the apparent contradiction.

\section{The Obligation to State Reasons for Courts' Decisions}

According to Dawson, the aforementioned 'revolution' started around 1800 , when laws in Germany obliged courts to explain to litigants the reasons for their decisions. Until the eighteenth century, courts kept the reasons for their decisions a secret. But the legal rules were not identical in every region that would later become Germany. Laws in some areas explicitly forbade publication of the court's reasons, whereas in other areas jurists interpreting Roman law simply did not recommend making reasons accessible. ${ }^{5}$ Allegedly, transparency as to reasoning would show the parties the way to attack the court's judgment with a legal remedy and would therefore undermine its authority. This argumentation gradually changed. Modern authors stood up for reasoned decisions. They argued that reasons could quieten the parties by showing the accuracy of the court's judgment. ${ }^{6}$

This changed point of view during the Age of Enlightenment stimulated lawmakers to prescribe reasoned judgments in the different

${ }^{4}$ Ibid., 432.

${ }^{5}$ H. Gehrke, Die privatrechtliche Entscheidungsliteratur Deutschlands, Charakteristik und Bibliografie der Rechtsprechungs- und Konsiliensammlungen vom 16. bis z. Beginn d. 19. Jahrhunderts (Frankfurt am Main, 1974), 26-31.

6 The discussion is analysed by S. Hocks, Gerichtsgeheimnis und Begründungszwang. Zur Publizität der Entscheidungsgründe im Ancien Régime und im frühen 19. Jahrhundert (Frankfurt am Main, 2002). 
territories, and later the states of the German Confederation. This began with Saxony in 1715, Bavaria then introduced the obligation between 1804 and 1820 and Prussia gradually obliged its judges to reveal their reasoning between 1781 and 1832, to name just the largest territories. As we can see from these dates, the process of establishing new laws took over a hundred years. Moreover, the obligation often started with the lower courts and was only then extended to other parts of the judiciary. ${ }^{7}$ In contrast to the English tradition of unofficial law-reporting, reasons had to be written by the judges of the court. Though it was possible for a clerk who was often a learned jurist to reconstruct the reasoning from notes, there was always an official version. It has been pointed out that these written reasons are a characteristic of European Continental law. ${ }^{8}$ English law reporters are on the contrary not the authors of the published opinion.

Besides explaining the result to the parties, this new obligation enabled judges and scholars to access the reasoning in prior cases. Various forms of collections flourished. The number of reported cases escalated in the 1830s and 1840s. Simultaneously, the citation of prior decisions became more common. Since then, and to the present day, it is hard to find a decision of a higher German court without references to the judiciary itself. ${ }^{9}$

\section{Collections of Decisions}

Clearly, the new legal obligation to write down decisions' reasons changed the courts' everyday work: they had to make the reasons accessible for the parties. Various contemporary discussions can be observed, starting from the issue of how to convince the parties, and not only fellow judges, to propositions as to how much the parties should pay for a clear copy of the motives. ${ }^{10}$ But, more importantly for this paper, a side-effect

7 R. Sprung, 'Die Entwicklung der zivilgerichtlichen Begründungspflicht', in R. Sprung (ed.), Die Entscheidungsbegründung in europäischen Verfahrensrechten und im Verfahren vor internationalen Gerichten (Vienna, 1974), 43-62.

${ }^{8}$ Reimann, 'Erosion der klassischen Formen', 232.

9 In the 1990s, around $96-99 \%$ of higher courts' decisions quoted previous decisions as precedents, counted for various German judiciaries by R. Alexy and R. Dreier, 'Precedent in the Federal Republic of Germany', in N. MacCormick and R. Summers (eds.), Interpreting Precedents (Aldershot, 1997), 17-64, at 23.

10 C. Günzl, Eine andere Geschichte der Begründungspflicht. Sichtweisen des frühen 19. Jahrhunderts (forthcoming, Tübingen, 2021). 
of the obligation to provide reasons for judgments was to establish new grounds for collections of legal decisions.

There had been a long tradition of juridical collections in Germany, stretching back to the Imperial Chamber Court, but in line with statutes it was strictly forbidden to publish reasoning. Nonetheless, the ambitious judges Andreas Gail (1526-87) and Joachim Mynsinger (1514-88) published internal reports in the sixteenth century. ${ }^{11}$ These reports were only meant to be noticed by other judges of the same panel, to prepare correct decisions. They were strictly confidential. Though the statutes were not changed, these internal reports built an essential part of the so-called Kameralliteratur. Diverse forms of collections existed in the eighteenth century before the duty to justify decisions was established. ${ }^{12} \mathrm{~A}$ final statement of the court as a panel was not formulated and therefore never included. Some lawyers simply published their assumptions as to what the court might have thought to justify its verdict and presented this as a collection of decisions. The confidentiality of the courts made it almost impossible to match the facts of a case and their legal interpretation. Thus, it was difficult to compare a current case to a prior one and then apply the same rules.

The new duty to justify every judgment to the litigants around 1800 changed collections fundamentally. Instead of being constrained by strict rules to hide reasoning, editors could now freely choose from numerous decisions. Though the reasons were supposed to explain the outcome to the parties, they were widely noticed amongst jurists. Different concepts of collections evolved. Some governments ordered official collections of the highest decisions. ${ }^{13}$ Courts became editors themselves. Other jurists collected at their own financial risk and asked their ruler for permission. ${ }^{14}$

\section{Seuffert's Innovative Collection}

Some decades later, the first nationwide collection started. In 1847, the former appellate judge Johann Adam Seuffert first published his famous

11 P. Oestmann, Wege zur Rechtsgeschichte: Gerichtsbarkeit und Verfahren (Cologne, 2015), 176.

12 For categories of German collections in the early modern age see Gehrke, Die privatrechtliche Entscheidungsliteratur.

13 A. H. Simon and H. L. von Strampff (eds.), Entscheidungen des Königlichen Geheimen Ober-Tribunals (Berlin, 1837), iii.

14 F. G. L. Strippelmann (ed.), Neue Sammlung bemerkenswerther Entscheidungen des OberAppellations-Gerichtes zu Cassel, part 1 (Cassel, 1842), iv. 
collection of decisions. He established a cross-regional collection of decisions and named it 'Archiv für Entscheidungen der obersten Gerichte in den deutschen Staaten' - 'Archive for Decisions of the Highest Courts in the German States'. Simply copying extracts from existing collections, Seuffert assembled reasonings of almost every German High Court of Appeal side-by-side, structured by topics. Thus, the reasonings in his collection were modified twice compared to the original version, in being extracts and in being summarized again. In 1857, his son, Ernst August Seuffert, continued the collection. From 1858 onwards the name 'J. A. Seuffert' preceded the title, to honour the deceased founder. In quotations and colloquial usage, the collection was called 'Seuffert's Archiv'. A former judge took over the editorship in 1863, but in the foreword he promised to stick to the principles that the Seuffert family had established. ${ }^{15}$ The collection was printed until 1944.

The founder, Johann Adam Seuffert (1794-1857), was a professor of history, the pandects and Bavarian Civil law in his hometown Würzburg, where he became a member of the Assembly of Estates (Ständeversammlung). In this position, he fought against censorship in 1831. As a punishment, he lost the permission to teach at Bavarian universities and was transferred to different mid-level courts in the state. In 1839, he asked for early retirement and settled down in Munich, publishing political essays and poetry under a pen name. Above all, he was a private scholar and wrote legal textbooks and commentaries. Among his works, his collection of decisions was immensely successful. ${ }^{16}$

The volumes of Seuffert's Archiv follow a simple structure. Some volumes open with an informative introduction, such as the first volume, which gives the collection's purpose, or a later volume, which tells of the change of editors. Originally, four booklets were sold separately, as we can see from four separate coversheets per volume. They were later compiled in hardback books. The core parts are the entries of decisions. The length of the entries differs, but on average they cover one page. Every entry has a number for ease of reference. At the beginning, every entry lists similar decisions in previous volumes, by volume and entry number. The decision itself is reduced to the main issue and rarely

15 J. A. Seuffert's Archiv für Entscheidungen der obersten Gerichte in den deutschen Staaten, 17(1) (1863), i (edited by A. F. W. Preusser).

${ }^{16}$ For Seuffert's biography see A. Quentin, 'Johann Adam Seuffert (1794-1857)', in Oberlandesgericht Nürnberg (ed.), In Stein gehauene Rechtsgeschichte aus zwei Jahrtausenden (Nuremberg, 2008), 12-17. 
repeats the parties' names. At the end, every entry specifies the source, for example a regional collection. A volume of Seuffert's collection assembles around two-hundred-and-fifty shortened decisions. To make all this information accessible, the collection used a structure well known to its readers, that is the order of material in legal textbooks at the time. This order, also called the Pandektensystem, goes back to Georg Arnold Heise, a professor from Göttingen, who used this structure in the early 1800s to teach Roman law to students. The Pandektensystem starts with a general part containing aspects such as sources of law or general principles. They are valid for the coming four parts unless an exception is stated there. The next parts contain property law and law of obligation. The last two parts are dedicated to family law and inheritance law. Detailed subsections enable jurists to find answers quickly. However, the abstract order is hard to understand at first sight. Up to today, Heise's Pandektensystem is the basis of the Bürgerliches Gesetzbuch, the German Civil law code. ${ }^{17}$ Seuffert, the founder of the archive, was one of Heise's students. He first adapted this system for his own textbook in $1825 .{ }^{18}$ In the Archiv, he did not refer to the Pandektensystem explicitly. However, the structure of every single booklet follows it, as does the register at the end of every compiled hardback book.

In the foreword to the first volume Seuffert explained that he started the collection to enable the integration of theory and practice. According to Seuffert, the connection between theory and practice was weak due to the Historical School of Law (Historische Rechtsschule). ${ }^{19}$ Theorists would not notice collections of decisions anymore. ${ }^{20}$ So Seuffert 'felt the need' to establish this cross-regional collection. Perhaps influenced by the Romanticism of his time, his argumentation was not purely rational. By establishing a collection covering decisions from all over Germany, he carefully contributed to the national movement on the eve of the 1848/9 German revolution. He hoped to support the unification of Civil law.

17 M. Schmoeckel, 'Vorbemerkung Vor $\$ 1$ ', in M. Schmoeckel, J. Rückert and R. Zimmermann (eds.), Historisch-kritischer Kommentar zum BGB (Tübingen, 2003), 123-65, at 137-8 (Rn. 20f).

18 J. A. Seuffert, Praktisches Pandektenrecht, 3rd edn, 3 vols. (Würzburg, 1852), vol. I, vii reprints the foreword from his first edition in 1824 in which he refers explicitly to Heise.

19 For the Historical School of Law, see H.-P. Haferkamp, Die Historische Rechtsschule (Frankfurt am Main, 2018).

20 J. A. Seuffert (ed.), Archiv für Entscheidungen der obersten Gerichte in den deutschen Staaten, vol. I (Munich, 1847), iii. 
His work was a great success, as we can see from the remarks of contemporaries. August Ludwig Reyscher, a famous scholar and politician of the time, showed his appreciation for the collection in a journal. $\mathrm{He}$, although not Seuffert himself, called the entries in the collection 'Präjudizien'. He was convinced that the given cases would not prevent courts from gaining better insight into a new case, but - I quote from Reyscher's review - 'in a certain manner' they would prevent a different opinion. Reyscher assumed it could be more 'convenient' to stick to the other court's point of view rather than establishing a different one. ${ }^{21}$ Another writer, Johannes Emil Kuntze, observed a change in the method of jurists around 1850 and saw Seuffert's Archiv replacing the Zeitschrift für historische Rechtswissenschaft, the main journal of the Historical School of Law. ${ }^{22}$ Rudolf von Jhering, in his later years a famous critic of abstract jurisprudence, ${ }^{23}$ called Seuffert's Archiv a mirror of and a reliable guide to the judiciary. ${ }^{24}$

\section{Precedents according to Nineteenth-Century German Doctrine}

However, would this quantity of reprinted decisions have any effect on future cases? The new availability of decisions encouraged a lively debate about the binding effect of prior decisions among scholars. ${ }^{25}$ The keyword in German is 'Präjudiz', which describes the consequences of a prior case on upcoming ones. An adequate translation is hard to find. It

${ }^{21}$ A. L. Reyscher, 'IX. Archiv für Entscheidungen der obersten Gerichte in den deutschen Staaten, herausgegeben von J. A. Seuffert (Appellationsgerichtsrath). Ersten Bandes erstes Heft. München 1847', Zeitschrift für deutsches Recht und deutsche Rechtswissenschaft, 11 (1847), 312-16, at 312: 'aber sie hindert sie [eine spätere bessere Ueberzeugung] gewissermaßen doch, weil es bequemer ist, einen Vorgang anzuziehen'.

22 J. E. Kuntze, Der Wendepunct der Rechtswissenschaft (Leipzig, 1856), 7: 'Die Zeitschrift für historische Rechtswissenschaft verstummt, - und was vermag unsere neue Zeit dagegen einzusetzen? Seuffert's Archiv für Entscheidungen der oberen Gerichtshöfe hat es seit mehreren Jahren übernommen, den reichen Springquell einer immer sich verjüngenden Kasuistik über unsere nahrungsbedürftige dürre Doktrin mit schätzenswerther Emsigkeit ausströmen zu lassen.'

${ }^{23}$ For a short summary in English, see H.-P. Haferkamp, 'Legal Formalism and Its Critics', in H. Pihlajamäki, M. D. Dubber and M. Godfrey (eds.), The Oxford Handbook of European Legal History (Oxford, 2018), 929-44, at 933-6.

${ }_{24}$ R. von Jhering, Scherz und Ernst in der Jurisprudenz, 13th edn (Leipzig, 1924), 101.

25 Dawson, Oracles of the Law, 440. At the same time, England established binding precedents in their purest form. See Reimann, 'Erosion der klassischen Formen', 217; S. Vogenauer, 'Zur Geschichte des Präjudizienrechts in England', Zeitschrift für Neuere Rechtsgeschichte, 28 (2006), 48-78, at 64. 
is a combination of precedent and prejudice. It does not indicate on its own whether the previous decision is binding for future cases or simply deals with similar facts. ${ }^{26}$

Scholars debated whether prior decisions were already binding according to Roman law, which had been changed and adapted over centuries (Gemeines Recht). Past decisions would be legally binding if they had the quality of a source of law. Some argued that the usage of courts (Gerichtsgebrauch) could produce customary law (Gewohnheitsrecht), the main source of law according to the leading Historical School of Law. Hence, the outcome would be binding for the future. But this theory had some discrepancies. A judgment was imposed on the parties by jurists and did not evolve over a long time like customary law. Consequently, the majority did not accept a legally binding effect of the usage of courts. ${ }^{27}$ A decision was valid law only for the specific case. ${ }^{28}$ Still, earlier decisions had some authoritative value if the solution was correct from a legal point of view. ${ }^{29}$ Until today, German case law as private law $^{30}$ remains in this rather unclear position: judge-made rules are generally not binding but have a high persuasive value. ${ }^{31}$ While judgments are theoretically not considered a source of law, practice widely considers and often adopts opinions of higher courts. Editors used the word 'Präjudiz' to stress the importance of collections, especially in their forewords, and in some states of the German Confederation the legislator passed so-called Präjudiziengesetze, trying to bind the lower courts to principles decided by higher courts. ${ }^{32}$ This was, however, an exception and did not lead to a strict stare decisis. ${ }^{33}$

${ }^{26}$ H.-J. Becker, 'Präjudiz', in A. Erler and E. Kaufmann (eds.), Handwörterbuch zur deutschen Rechtsgeschichte, vol. 3 (Berlin, 1984), cols. 1866-70.

27 J. Schröder, Recht als Wissenschaft 2nd edn (Munich, 2012), 200.

28 R. Ogorek, Richterkönig oder Subsumtionsautomat? Zur Justiztheorie im 19. Jahrhundert (Frankfurt am Main, 1986), 196.

29 Dawson, Oracles of the Law, 441: 'their products acquired authority by meeting the test of legal science'.

30 An exception is fields of law that consist merely of case law, such as employment law.

${ }^{31}$ M. Payandeh, Judikative Rechtserzeugung, Theorie, Dogmatik und Methodik der Wirkungen von Präjudizien (Tübingen, 2017).

32 Ogorek, Richterkönig oder Subsumtionsautomat?, 193-6.

${ }^{33}$ For a different view, see U. Müßig, 'Geschichte des Richterrechts und der Präjudizienbindung auf dem Europäischen Kontinent', Zeitschrift für Neuere Rechtsgeschichte, 28 (2006), 79-106, at 80. 


\section{The One and Only Decision}

Even if higher courts follow a certain opinion, it could be wrong. German scholars of the nineteenth century, probably influenced by the philosophy of German idealism, assumed that there was only one true and right solution to every case. The task is to find it. A previous decision must not prevent the judge from searching for the right solution. This search for the truth implies that the law provides adequate results to every legal problem. But a court could have been wrong when deciding the case in the first place. ${ }^{34}$ Hence, a prior case should not be legally binding. ${ }^{35}$ This is probably the main difference from Common law countries, where, by acknowledging prior cases as binding law, the decision becomes a source of law itself. The Common law way is a practical approach that guarantees predictability of legal decisions. Yet, it is not compatible with the subliminal ideal of only one lawful decision which is independent from the current jurisdiction. ${ }^{36}$ In that logic, the result of a legal dispute cannot replace the already existing law even if no one had ever thought about this ideal correct solution.

The search for a correct solution also had practical effects for other legal issues. For instance, it played a major role in the concurrent discussion as to who was to bear the costs of a legal dispute. ${ }^{37}$ The old doctrine stated the losing party had to pay unless they could prove the outcome was unforeseeable. It seemed unfair to impose the burden of costs on someone who did not know better in advance. Litigants safeguarded themselves against the financial risk by expert reports. If legal experts assured them that they would surely win their case, a later loss was unforeseeable. This changed radically when Adolph Dietrich Weber published his book about the costs in legal disputes in 1788. He argued that the right solution to every case was fixed even before the dispute arose. This one and true decision was already hidden in the law. From now on, the losing party had to bear the costs with very few exceptions.

34 Also suggested in ibid., 106.

35 T. Herbst, 'Die These der einzig richtigen Entscheidung', JuristenZeitung, 18 (2012), 891-900.

${ }^{36}$ Ogorek, Richterkönig oder Subsumtionsautomat?, 196.

37 W. Sellert, 'Die Akzessorietät von Kostentragung und Prozeßerfolg, ein historisches Problem von aktueller Bedeutung', in H.-J. Becker (ed.), Rechtsgeschichte als Kulturgeschichte, Festschrift für Adalbert Erler zum 70. Geburtstag (Aalen, 1976), 509-37. 


\section{Issue and Method}

Despite scholars' reservations concerning case law, collections of the time made prior cases widely available. On the one hand, the doctrine is clear and does not see prior decisions as having a legally binding effect. On the other hand, current research assumes a huge impact of prior cases to future decisions. Surprisingly, until now, scholars have paid little attention to how this worked in practice. How did courts and collections argue using concrete cases decided in the past? In suggesting one approach to answer this question, the following part compares four different versions of a single case. They are different stages, from a handwritten report to a shortened entry in Seuffert's Archiv. First of all, a single judge gave his opinion in a report. Secondly, the committee of judges based its reasoned judgment on that report. Thirdly, the reasons were shortened for a regional collection which printed it. Finally, 'Seuffert's Archiv' published parts of this last version. The example given here reveals the degree to which prior cases predetermined future courts' decisions. Certainly, generalisations from this one case are dangerous. However, by choosing an example from an influential court reprinted in an influential collection, the instance is likely to represent a common and acknowledged technique of the time. This case is a suitable paradigm for at least three reasons: all four versions of the case are preserved; the case contains past judicial quotations in every version; and, finally, the reasoned judgment is quite short and may be examined as a whole, containing as it does only two legal problems.

\section{A Court File Becomes an Entry in Seuffert's Archiv}

Let us have a closer look at Seuffert's Archiv. How did entries in it arise from a report or a decision? What role did prior decisions play in it? The following analysis focuses on the argumentation and the way the different versions mention prior cases and other authorities. The legal issue still plays a role, as the following example will show.

Let us examine a legal dispute that took place in the 1850s in the city of Hamburg. The plaintiff was a widow named Schäuffler. She was represented by a curator ad litem. This was necessary for her lawsuit. Although women in general had legal capacity in the nineteenth century, ${ }^{38}$ the city

38 H. Coing, Europäisches Privatrecht, 2 vols. (Munich, 1989), vol. II, 291: 'Die Frau ist geschäftsfähig. Die im Mittelalter vorhandene und im älteren gemeinen Recht territorial aufrechterhaltene Geschlechtsvormundschaft existiert nicht mehr.' 
of Hamburg had its own particular rules. ${ }^{39}$ The statutes limited women's legal capacity, especially in court. ${ }^{40}$ The represented plaintiff demanded that the defendants pay interest. The defendants were the heirs of an alleged debtor named Voigt. The legal relationship from which this interest derived is not named clearly. Yet, the defendants refused to pay further interest, arguing the debt never existed at all.

The High Court of Appeal residing in Lübeck decided the case in April 1856. This court was competent to rule in cases from Hamburg, Bremen, Frankfurt and Lübeck - the four last remaining free cities within the German Confederation. The court had a particularly good reputation due to its highly qualified and hardworking judges. ${ }^{41}$ Incidentally, the abovementioned Georg Arnold Heise left university to preside over the court in 1820 and kept this important legal practitioner's position until his death in 1851. The High Court of Appeal in Lübeck was influential far beyond its time. For instance, it developed most of Germany's commercial law. ${ }^{42}$

The schema that appears at the end of this essay presents four versions in separate columns. ${ }^{43}$ The left column shows the argumentation of the single judge, Hermann Friedrich Brandis, who prepared the decision in a report. The second column shows the official reasons presented by the court for the parties. A regional collection gave a summary of these reasons (third column), and finally Seuffert's Archiv provided a shortened version of this summary (right column).

The internal report of the judge served as a preparation for the panel of seven judges to decide the case. It took judge Brandis from 30 December

E. Holthöfer, 'Die Geschlechtsvormundschaft. Ein Überblick von der Antike bis ins 19. Jahrhundert', in U. Gerhard (ed.), Frauen in der Geschichte des Rechts (Munich, 1997), $390-451$, at 421.

40

Der Stadt Hamburg Gerichts-Ordnung und Statuta (Hamburg, 1842), 503.

${ }^{41}$ For an overview in English, see P. Oestmann, 'Court Records as Sources for the History of Commercial Law: The Oberappellationsgericht Lübeck as a Commercial Court (1820-1879)', in H. Pihlajamäki, A. Cordes, S. Dauchy and D. De ruysscher (eds.), Understanding the Sources of Early Modern and Modern Commercial Law: Courts, Statutes, Contracts, and Legal Scholarship (Leiden, 2018), 364-85, at 369-71.

42 J. Rückert, 'Handelsrechtsbildung und Modernisierung des Handelsrechts durch Wissenschaft zwischen ca. 1800 und 1900' in K. O. Scherner (ed.), Modernisierung des Handelsrechts im 19. Jahrhundert, Abhandlungen aus dem gesamten bürgerlichen Recht, Handelsrecht und Wirtschaftsrecht (Heidelberg, 1993), 19-66; P. Oestmann, 'The Unification of Law via the Institution of Jurisdiction in the 19th Century: Commercial Law before the High Court of Appeal of the Four Free Cities of Germany', Juridica International, 16 (2009), 224-30.

43 For the schema, see below, 224-35. 
1854 to 9 April 1856 to hand in the report. This document is by far the longest of the four versions, containing aspects that the panel of judges later regarded as irrelevant for the official statement of reasons.

It is notable that the structure of the reasons in the second column is entirely the same as in the first. The judgment is therefore based on the report and repeats its structure, argumentation and most of the sentences. It was tempting simply to copy the report, though some laws of the time and scholars explicitly militated against this, ${ }^{44}$ and the guidelines in legal textbooks proposed not simply copying the reasons from the report to prevent this exact scenario. ${ }^{45}$ Yet it was highly likely that the group of judges would confirm the reporter's opinion without carefully looking at the issues, and the prestigious court in Lübeck followed the proposal. Nevertheless, the reasoned decision is shortened, and the language slightly differs in comparison to the report, as we shall see. While the report serves to make an adequate decision, the reasons aim at explaining them convincingly to the parties and the public.

In 1859, that is, three years later, a regional collection quoted as 'Hamburger Sammlung' (column three) made the decision available to a wider audience. ${ }^{46}$ It repeated decisions made by the High Court of Appeal in Lübeck dealing with cases from the city of Hamburg. The whole volume is dedicated to decisions of the year 1856. A second regional collection also reprinted the case. ${ }^{47}$ Temporarily, Hamburg had two regional collections with the highest court's decisions. However, the analysis focuses on the first one, since Seuffert's Archiv quotes this version.

It was not until 1863 that the case appears in Seuffert's Archiv. Even seven years after the judgment, the case was found to be worthy of being told to a readership beyond the court's jurisdiction. Therefore, the up-todateness of a decision was not the main aspect. The new editor of Seuffert's Archiv probably learned of the case from the Hamburg

${ }^{44}$ See for instance, Königlich-Baierisches Regierungsblatt, 1813, col. 565.

${ }^{45}$ For an example, see J. K. Gensler, Grundsätze der juristischen Vortrags- und formellen Entscheidungskunde (Jena, 1815), 57-8.

${ }^{46}$ J. F. Voigt (ed.), Sammlung von Erkenntnissen und Entscheidungsgründen des OberAppellations-Gerichts $z u$ Lübeck in hamburgischen Rechtssachen nebst den Erkenntnissen der unteren Instanzen, vol. III, part 1: Erkenntnisse aus dem Jahr 1856 enthaltend (Hamburg, 1859, 1864), 57-60.

47 Anonymous, Vollständige Sammlung der vom Ober-Appellations-Gerichte zu Lübeck im Jahre 1856 in hamburgischen Rechtssachen abgegebenen Urtheile sammt Motiven, mit den Vorentscheidungen der verschiedenen Unterinstanzen (Leipzig, 1859), 130-8. 
collection, which he quoted. A detailed examination of the attached schema demonstrates differences between the versions row by row.

\section{Headline and Guiding Principles}

To facilitate the readers' orientation in a legal document, a headline or a guiding principle may be used as an introduction. Guiding principles (Leitsätze) help readers from outside the court gain better insight. These principles can be official, that is proposed by the court, or unofficial, that is added by the publisher. In Schäuffler v. Voigt's heirs, the initial report and the judges' reasons for the decision do not contain a headline or a guiding principle. These two versions were not created to be printed. In contrast, the regional collection as well as Seuffert's Archiv indicated the main issues by a preliminary sentence. Thus, the editors who stood outside the judiciary freely chose the headlines. Other contemporary collections were influenced by the court if members of the court were also part of the editorial board. At the Kammergericht in Berlin, for instance, judges subsequently prepared the headlines themselves. ${ }^{48}$ From 1865 onwards, the High Court of Appeal in Lübeck had its own collection edited by the court's members. ${ }^{49}$

The regional collection describes the problems and the court's solution in a quite detailed manner, using abbreviated sentences. It says: 'Perennial debt-payments. Presumption thereof for a primary debt? This presumption is not plainly substantial; it is rather to be determined according to the special circumstances. Opinions of scholars on this matter. Interpretation of L. 6. $\$ 1$ de usuris 22.1.'

Seuffert's Archiv copied from the regional collection but omitted the complicated introduction. It indicated the main problem by a short and precise question: 'Do perennial debt-payments constitute an acknowledgement of the primary debt? ${ }^{50}$ Moreover, Seuffert's Archiv referred to similar cases in previous volumes in the headline.

\section{First Question of Law}

The case Schäuffler v. Voigt's heirs provided two major questions of law: one concerned admissibility, the other the use of a legal presumption.

48 Berlin, Geheimes Staatsarchiv Preußischer Kulturbesitz, I. HA Rep. 97a Nr. 443, 444, 446.

49 J. F. Kierulff (ed.), Sammlung der Entscheidungen des Ober-Appellationsgerichts der vier freien Städte Deutschlands zu Lübeck (Hamburg, 1865).

50 Original: 'Ist aus mehrjährigen Zinszahlungen eine Anerkennung der Capitalschuld zu folgern.' 
Firstly, the reporting judge Brandis discussed whether the High Court was competent to decide the case at all. The question whether the court had to deal with a case depended on the regulations of the free city where the case was decided on lower instance. According to Hamburg's statutes, the admissibility of the case depended on the value in litigation. ${ }^{51}$ The demanded interest of forty-eight marks was too low to lead to the High Court of Appeal's jurisdiction. As the defendants denied the overall entitlement of 1,190 marks, the reporting judge concluded, this was the real value in dispute and the court was therefore competent.

This question of admissibility is abbreviated in the schema. However, the preserved introductory sentence shows a remarkable aspect. The reporting judge uses the acronym 'm.E.', standing for 'meines Erachtens', which can be translated as 'in my point of view'. Thereby Brandis phrases clearly that he is expressing his own legal opinion on this issue, which is not the only one, and not necessarily correct. In the reasons for the judgment in the second column there is no longer any notion of this opinion being that of a single person with his own questionable opinion. Self-confident, the court expresses that there is no doubt ('kein Zweifel') about this particular outcome. This change in presenting a legal opinion has been an issue in recent studies. ${ }^{52}$ The regional collection for Hamburg reproduced this first question of law, starting with the same first sentence as the official judgment. As the attached schema indicates, Seuffert's Archiv left this part out and dedicated the entry completely to the other issue. This is an example of how Seuffert's cross-regional collection separated cases into their single problems, so that every entry dealt with only one legal question.

\section{Second Question of Law}

The reporting judge Brandis explains the second question of law in a long and complicated manner: 'Regarding the matter itself, the success of the remedy, which aims at the restitution of the judgment in first instance, depends completely on the answer to the legal question, what influence a perennial debt payment has on the existence or the proof of the initial debt. ${ }^{53}$

${ }^{51}$ H. Greb, Die Verfassung des Oberappellationsgerichts der vier freien Städte Deutschlands zu Lübeck (Göttingen, 1967), 94-5.

52 P. Oestmann, Zur Gerichtspraxis im 19. Jahrhundert, ein Schmuggeleiprozess am Oberappellationsgericht Lübeck (Cologne, 2019), 51-4.

53 Original: 'B. Soviel die Sache selbst betrifft, so hängt der Erfolg der aufgestellten alleinigen Beschwerde, welche auf Wiederherstellung des Erkenntnisses erster Instanz gerichtet ist, ganz u. gar von Beantwortung der Rechtsfrage ab, welcher Einfluß einer mehrjährigen 
This introduction named the various conditions. The judgment repeated this explanation of the legal issue while the Hamburg collection abbreviated the original section. Seuffert, on the contrary, left it out completely. He had already indicated the issue precisely in the opening headline. The entry of roughly two pages in Seuffert's Archiv is well arranged so readers can easily access the important information.

\section{Three Opinions}

After bringing up this issue, Brandis discussed the legal effects of past years' interest payments. He gave three opinions on this subject. The first claims that the payments of interest over a certain time constitute a debt in its own right, even if it did not exist before. Brandis assessed this point of view as fallacious, quoting eighteenth-century authors for this obsolete opinion. It was so far beside the point that it did not even appear in the courts' judgment.

The second opinion argues that past payments of interest create a legal presumption of the debt. It could still be possible to prove the contrary, but the burden of evidence would rest upon the debtor. Brandis quoted several authorities on this idea but classified it as a view rarely now advanced. The judgment as well as the two collections did not adopt all of the references.

The third opinion states that there is no such presumption of a debt. Therefore, the evidence has to be valued and assessed by the court according to the individual circumstances of the given case.

Besides scholars of the time, Brandis quoted two decisions of other German high courts of appeal. These were recorded within an older volume of Seuffert's Archiv. Writing his internal report, Brandis quoted from this cross-regional collection. This is apparently the only way in which he took notice of the decisions made by other high courts of appeal since he names Seuffert explicitly as a reference. Though the entries are shortened and slightly changed, as we have seen, Seuffert's Archiv was the principal source to consult for recent decisions.

Brandis's allegation refers to volume two of Seuffert's collection. The older entry contains only four lines stating: 'A ten-year payment of interest on its own does neither generate an obligation of those making the payment to keep paying in future, nor the obligation to repay the

Zinszahlung in Beziehung auf das Bestehen oder den Beweis einer Capitalschuld beizulegen sei.' 
initial debt. ${ }^{54}$ This short statement does not contain any argument but simply repeats the outcome of the case. The quotation from Seuffert's Archiv refers in a footnote to a journal that printed a 'Präjudiz' from Cassel with the exact same outcome for a thirty-year payment of interest.

This core part of Brandis's report is reproduced nearly word for word in the judgment and the two collections. Slight variation in spelling and abbreviations is presumably due to different bibliographic styles. The allegation of Seuffert's Archiv underlines the effort to unify the law. Though the High Court of Appeal in Lübeck was not legally bound by other high courts of appeals' decisions, it quoted and considered their opinions.

\section{Statement of the Judge}

However, Brandis does not simply follow the newest or somehow best authority when stating his preferred opinion. He names these opinions but discusses the best solution for the problem by explaining a fragment of Roman law. This fragment had already been used as an argument for the first and second opinion several times. According to Brandis, Roman law did not qualify interest payments differently from a partial payment or an inquiry to an extension of time. ${ }^{55}$ They were all indications for the existence of an initial debt but did not constitute a legal presumption or even a debt on their own. Both the court's presentation of its reasons and the two collections copied almost all of this elaborate statement. Again, the court removed the personal 'in my opinion' in the judgment. The court shows its decision as the only reasonable answer to the given problem. There is just a transcriptional error in Seuffert's Archiv, referring to twenty-two instead of thirty-two, and we can find different expressions for 'and so on' in the German of the time. ${ }^{56}$

The examination of the Roman law fragment goes on for several pages of the report. ${ }^{57}$ Brandis compared the case solved by Roman lawyers to his problem. He claimed it would not establish a general principle but

54 J. A. Seuffert (ed.), Archiv für Entscheidungen, vol. II (Munich, 1849), 339, no. 268: 'Eine zehnjährige Zinsenzahlung für sich allein begründet weder die Verbindlichkeit dessen, der sie bewirkte, zur ferneren Entrichtung dieser Zinsen, noch weniger seine Verpflichtung zur Zahlung des Capitals.'

55 Original: 'wie ein Gleiches auch durch andere Handlungen, z.B. eine Abschlagsbitte, Fristbitte pp. bekundet warden kann.'

56 i.e. 'pp.', 'etc.', 'u.s.w.'.

57 The following evaluation is not part of the schema below. 
was only the adequate solution in this case from antiquity. The circumstances of the old case were not mentioned in the Digest in detail. Brandis's method is close to that of distinguishing of cases in Common law. The fragment would deal only with a special problem of the dowry, he argued. Therefore, it was not comparable to the given case. A general presumption could not be included since it did not give any specific requirements such as the necessary duration of the debt payments. Brandis admitted that there were also contrary interpretations of the fragment by other authors. But he stuck with his strict interpretation. The beginning of the fragment also dealt with a different legal problem. There - for Brandis - the initial debt was acknowledged but the obligation to periodical debt payments was in question. Thus, Brandis consulted Roman law to solve his case in this part of the report, whilst carefully evaluating the similarities and differences between that law and his own case.

Brandis also quotes from textbooks and collections. Yet, these authorities are not sufficient to justify the outcome. Only a clear evaluation of Roman law could do so. Roman law was the only binding text for Brandis. For this method, Germany's scholars were admired at the time. ${ }^{58}$ Roman law gave not only a directive for research at university but served as a tool to solve legal issues in practice. The fragment itself was open to interpretation. In the end, Brandis followed the authorities of his time based on his understanding of the Digest.

\section{Application of the Legal Rule to the Case}

Only after he had decided this main issue did Brandis turn to the specific case of the widow who sued her alleged debtor's heirs for further payment of interest. Thus, he distinguished between a rule that he deduced from Roman law and the case to which it was applied. The outcome of the case was not a final judgment but a judgment in evidence, a so-called Beweisurteil. This was a typical form in deciding cases until the nineteenth century. The court ordered the plaintiff to prove that the defendants owed her money. If she succeeded, she would have won her case. The court agreed on this result, but the collections left it out. Even the local collection from Hamburg surprisingly omitted it, although it published the parties' names.

58 See S. Vogenauer, 'An Empire of Light? Learning and Lawmaking in the History of German Law', Cambridge Law Journal, 64 (2005), 481-500, at 481. 


\section{Conclusion}

In summary, Seuffert's Archiv enabled judges in different German states to take notice of each other's reasoned decisions and made quotations easier. It has been described as a precursor of modern online databases where the newest decisions can be consulted. ${ }^{59}$ Thereby, decisions became an authority among other academic opinions for the ruling of new cases in court. In compliance with contemporary doctrine, a prior decision on its own was not sufficient to justify the outcome of a case. This was only possible by evaluating the applicable (Roman) law. 'Präjudizien' served purely as references or authorities and were not examined as sources of law like Roman law. Other courts' opinions did not bind the judges yet made them at least consider the given arguments.

In the case of the widow Schäuffler, the court finally followed the two 'Präjudizien' of other high courts of appeal that it accessed via Seuffert's Archiv. As Reyscher had stated in 1847, it was easier to follow the existing guideline. Of course, there are also counterexamples where courts deviated from outcomes reprinted in Seuffert's Archiv. ${ }^{60}$ Yet, the entries constituted a source of legal inspiration and orientation. ${ }^{61}$

Dawson's notion of a 'Case-Law Revolution' evokes associations of binding precedents for future cases. For the middle of the nineteenth century in Germany, this is incorrect. However, if one wants to stick to the comparison between Civil law and Common law, the effects of the German 'Präjudizien' of the time resemble most closely those of persuasive precedents in Common law countries today. Prior decisions might be used as guidelines which the court could follow. This underlines the German political structure of the time and the constitution of the courts. Every state had its own highest court and was not legally bound to any other courts. However, by taking other courts' decisions into account, courts showed their respect to each other. This process can be described as a conversation between higher courts. Without any incentive from the German Confederation or the single states, the courts worked in this way on a unification of the Civil law.

59 Quentin, 'Seuffert', 17.

60 M. Berger, C. Günzl, and N. Kramp-Seidel, 'Normen und Entscheiden, Anmerkungen zu einem problematischen Verhältnis', in U. Pfister (ed.), Kulturen des Entscheidens, Narrative - Praktiken - Ressourcen (Göttingen, 2019), 248-66.

61 Similarly, see Vogenauer, 'Zur Geschichte des Präjudizienrechts in England', 59, referring to England in the seventeenth and eighteenth centuries. 


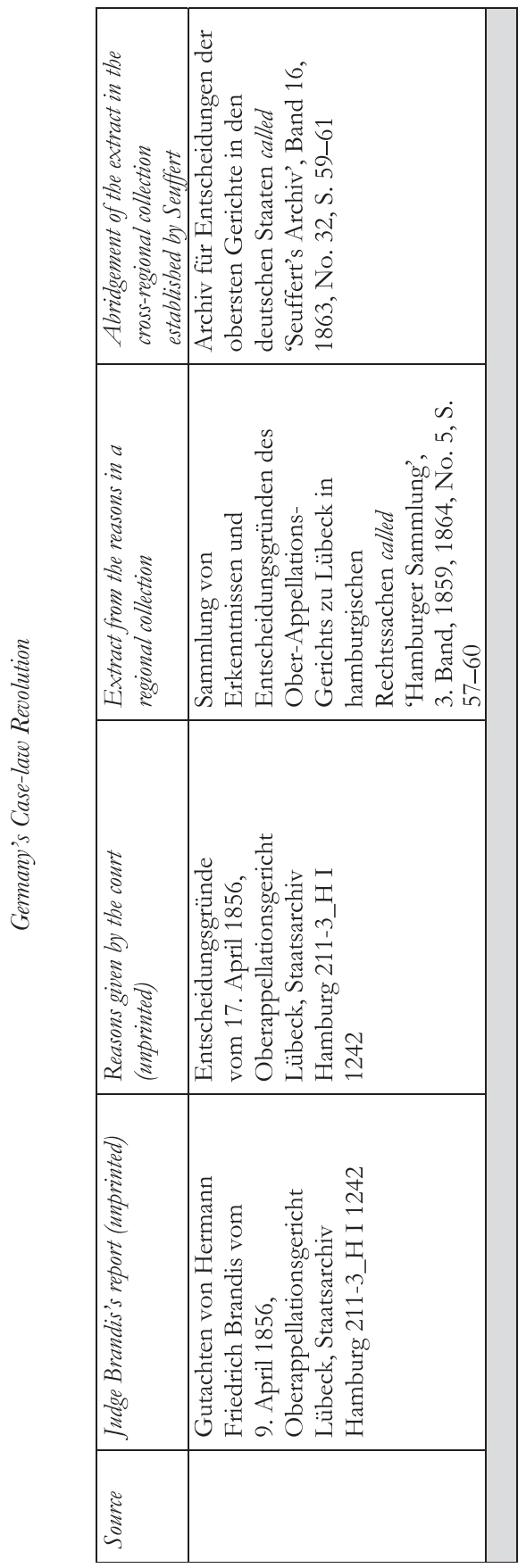

224 


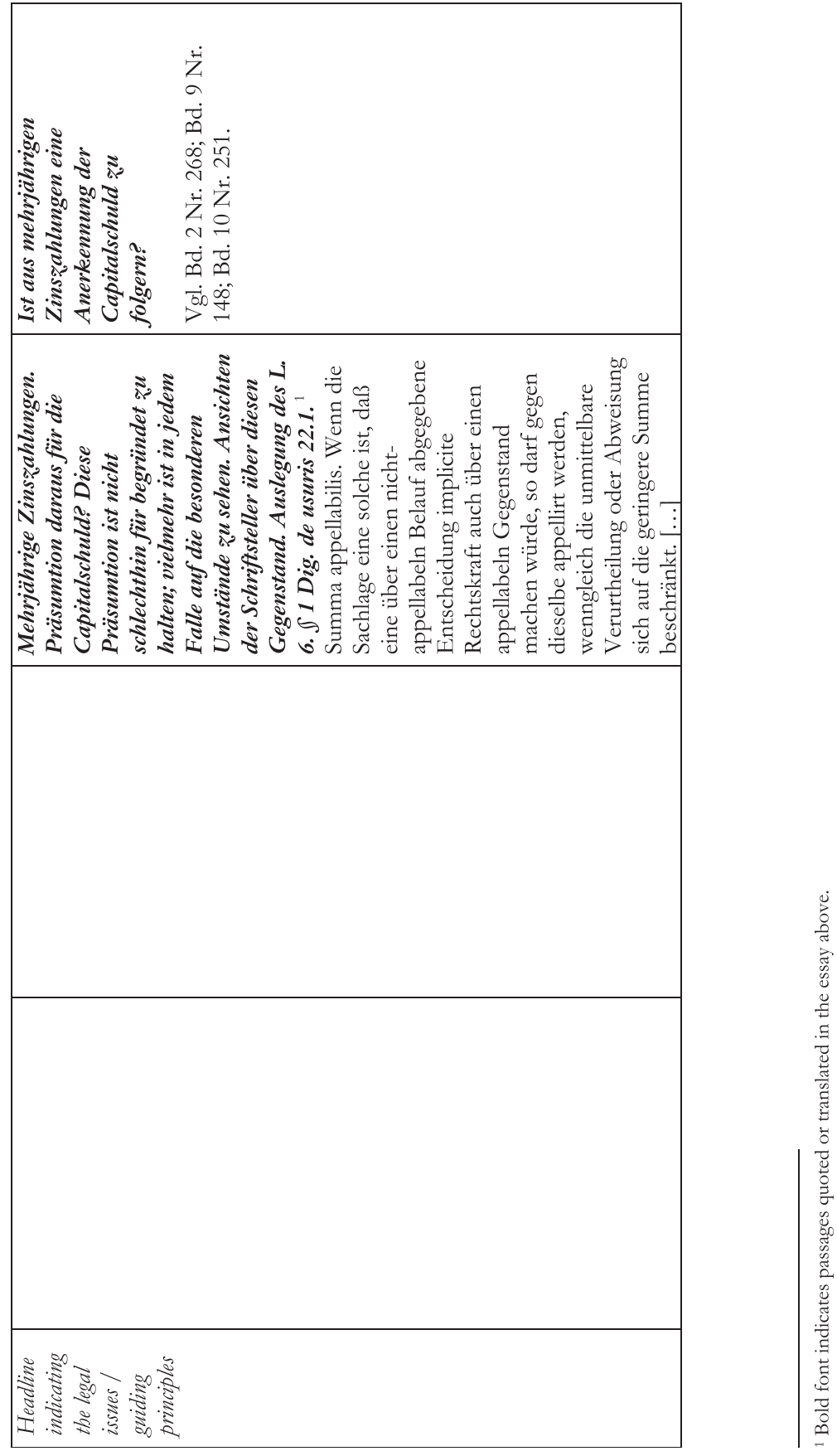

225 


\begin{tabular}{|c|c|c|}
\hline 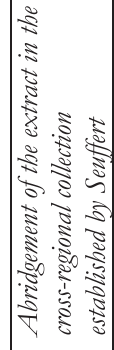 & & \\
\hline 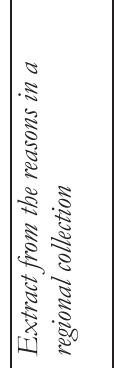 & 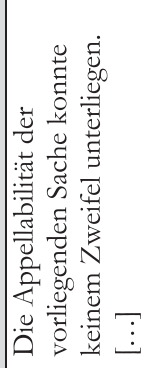 & 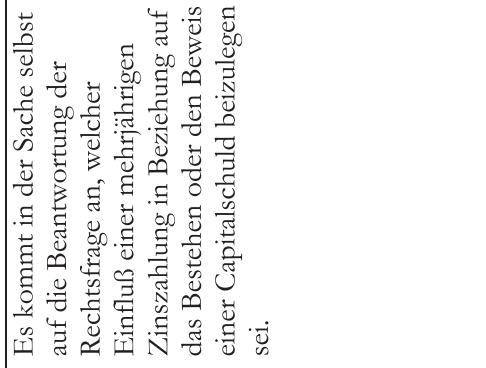 \\
\hline 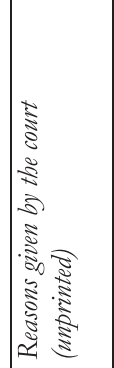 & 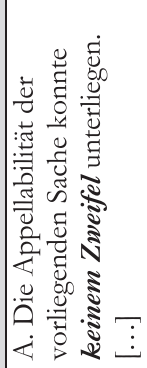 & 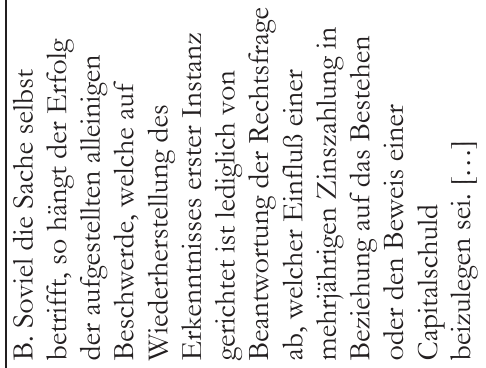 \\
\hline 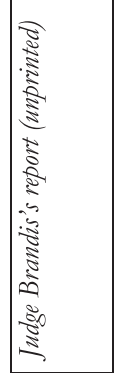 & 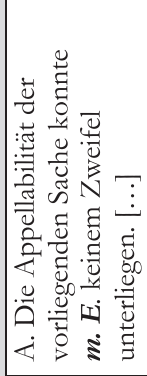 & 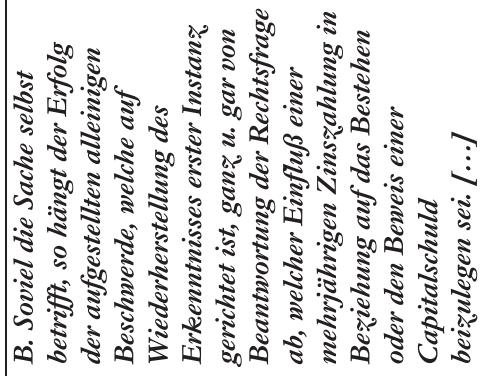 \\
\hline हूँ & $\frac{3}{3}$ & (3) \\
\hline
\end{tabular}




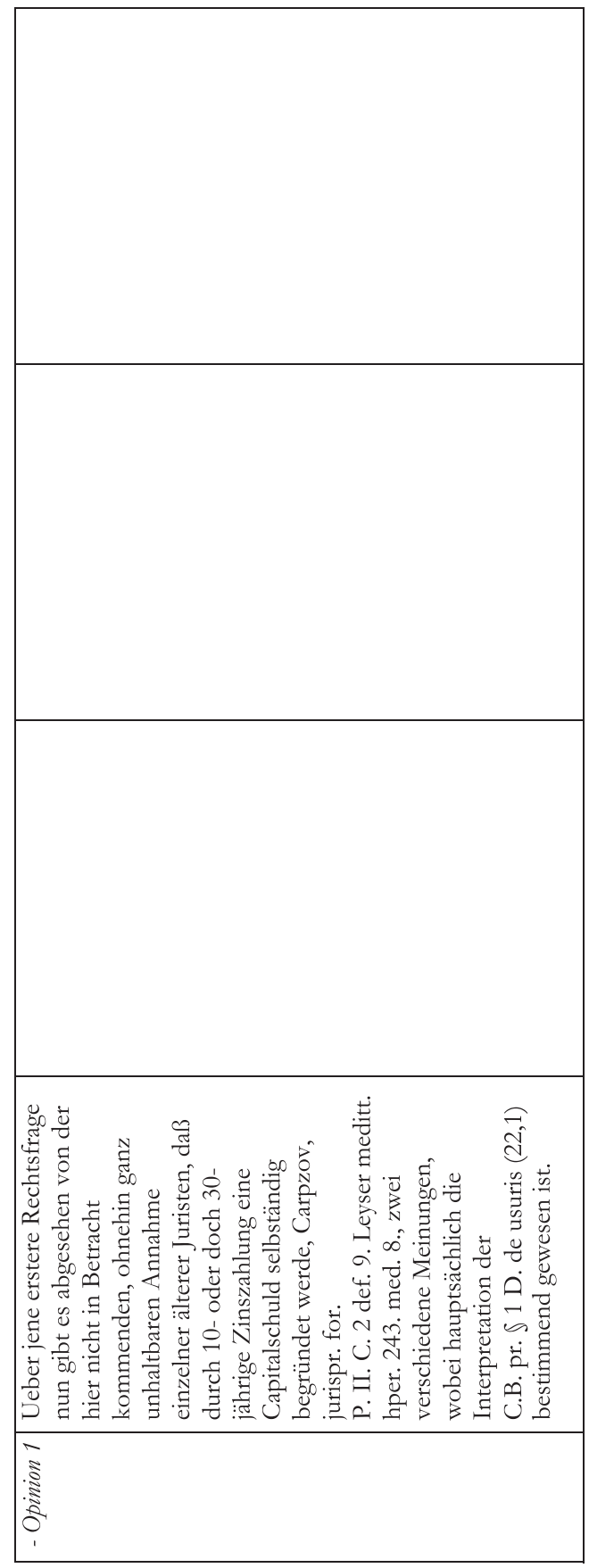




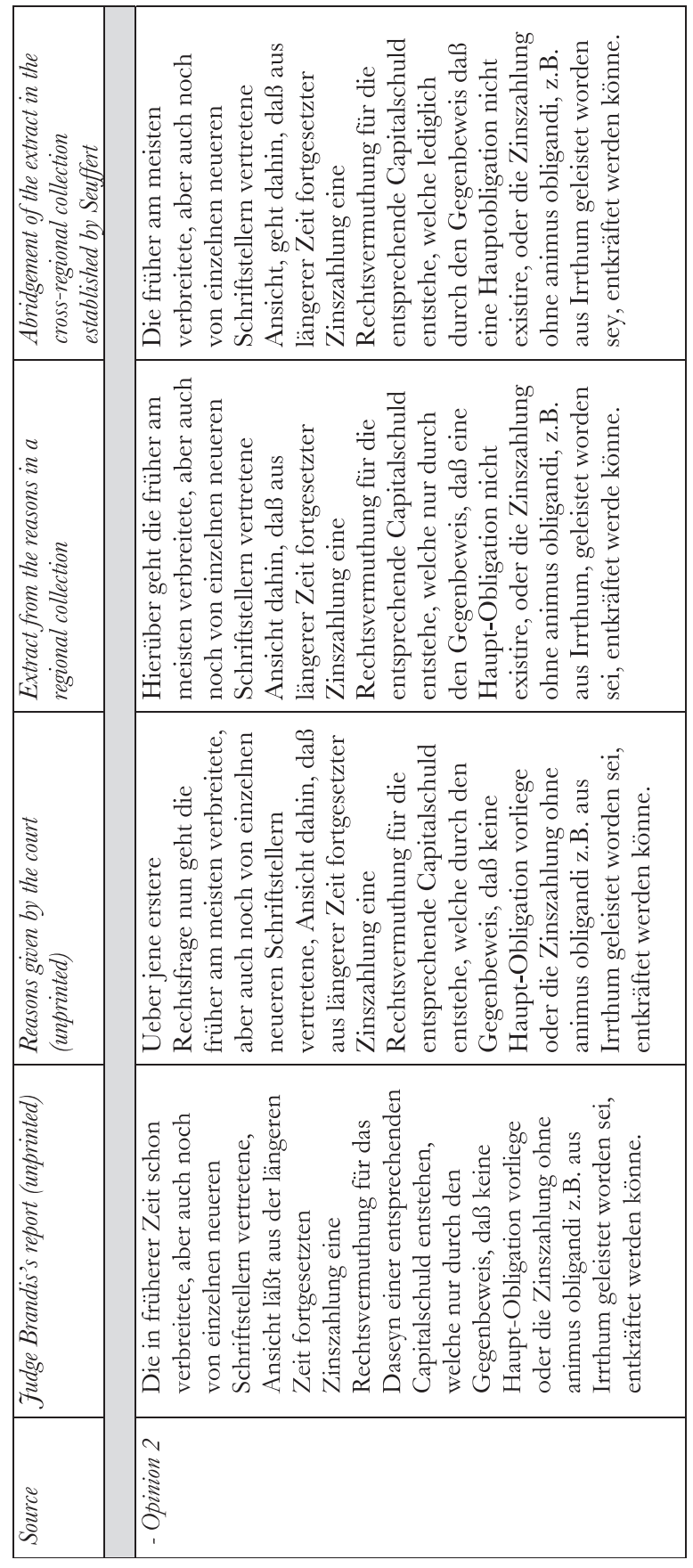

228 


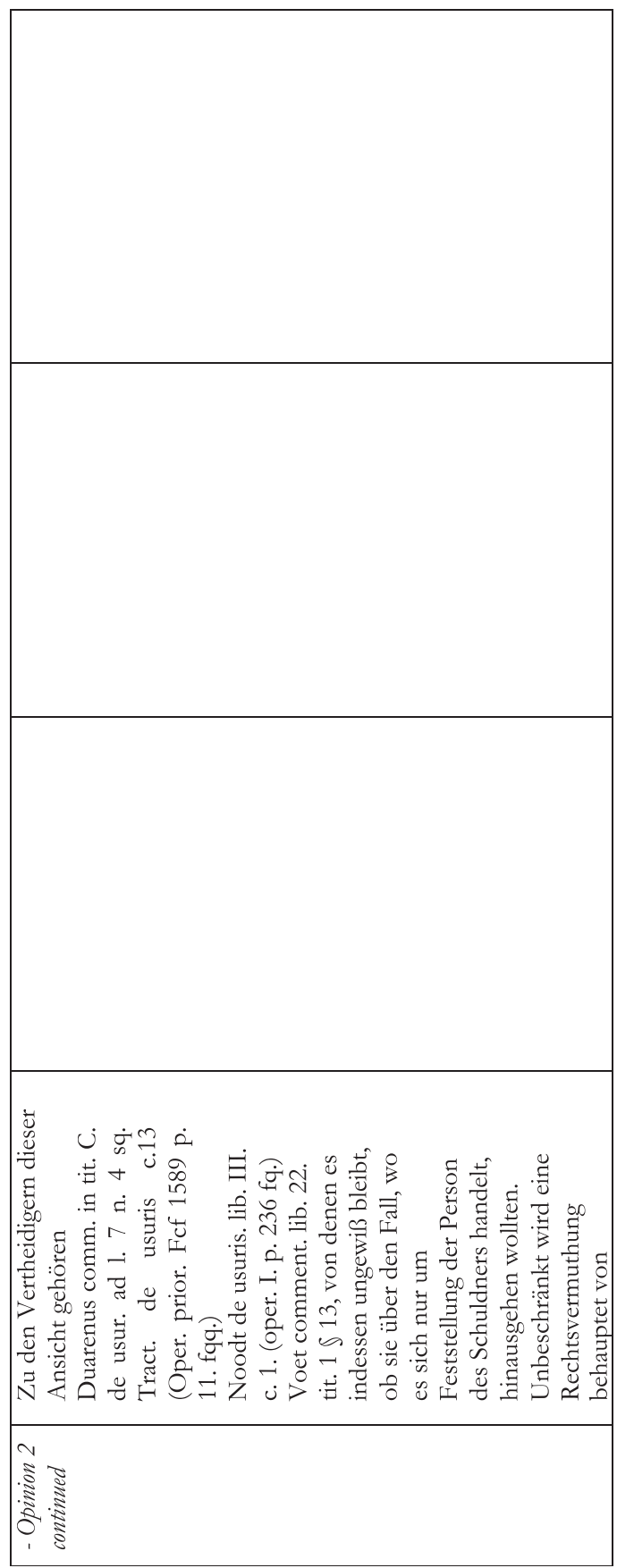

229 


\begin{tabular}{|c|c|c|}
\hline 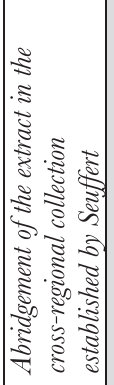 & 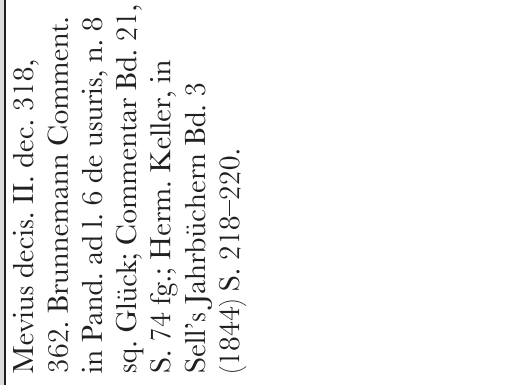 & 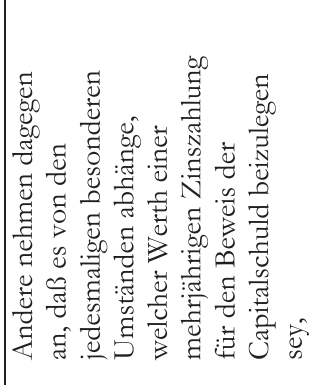 \\
\hline 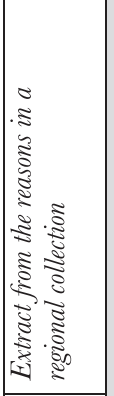 & 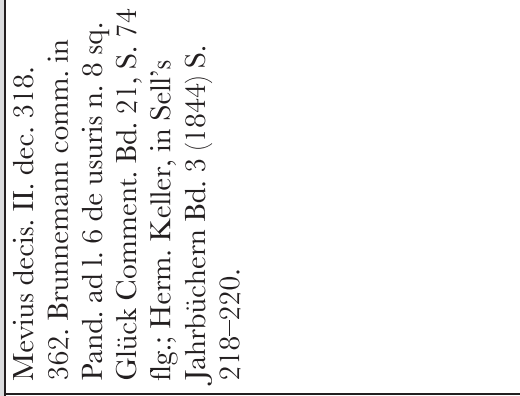 & 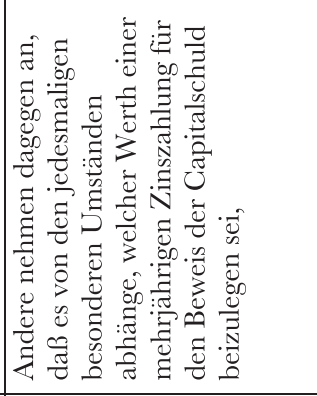 \\
\hline 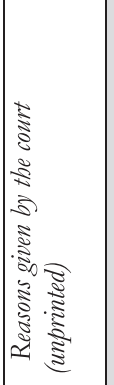 & 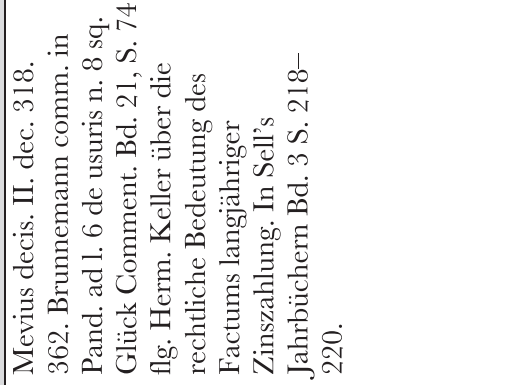 & 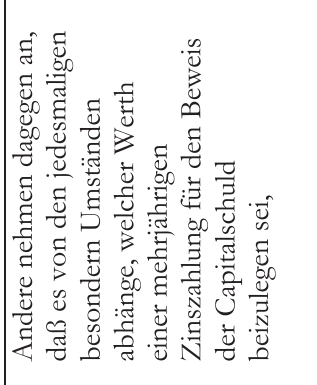 \\
\hline 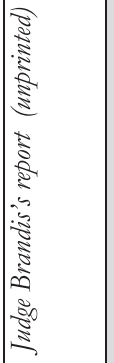 & 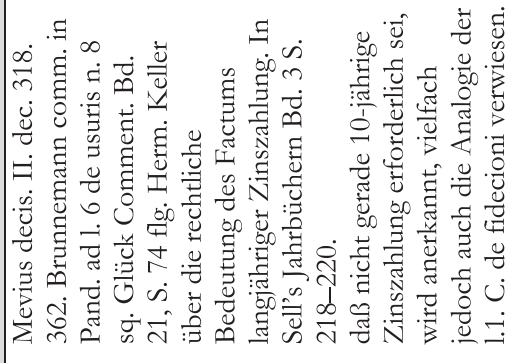 & 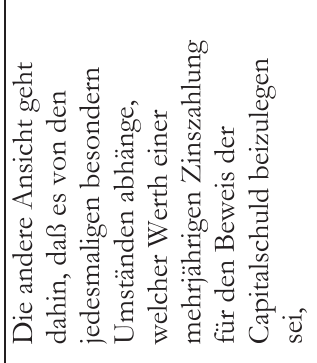 \\
\hline 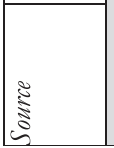 & 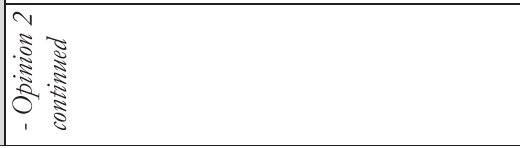 & 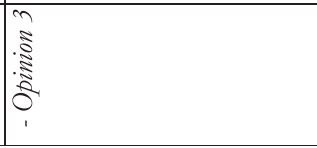 \\
\hline
\end{tabular}




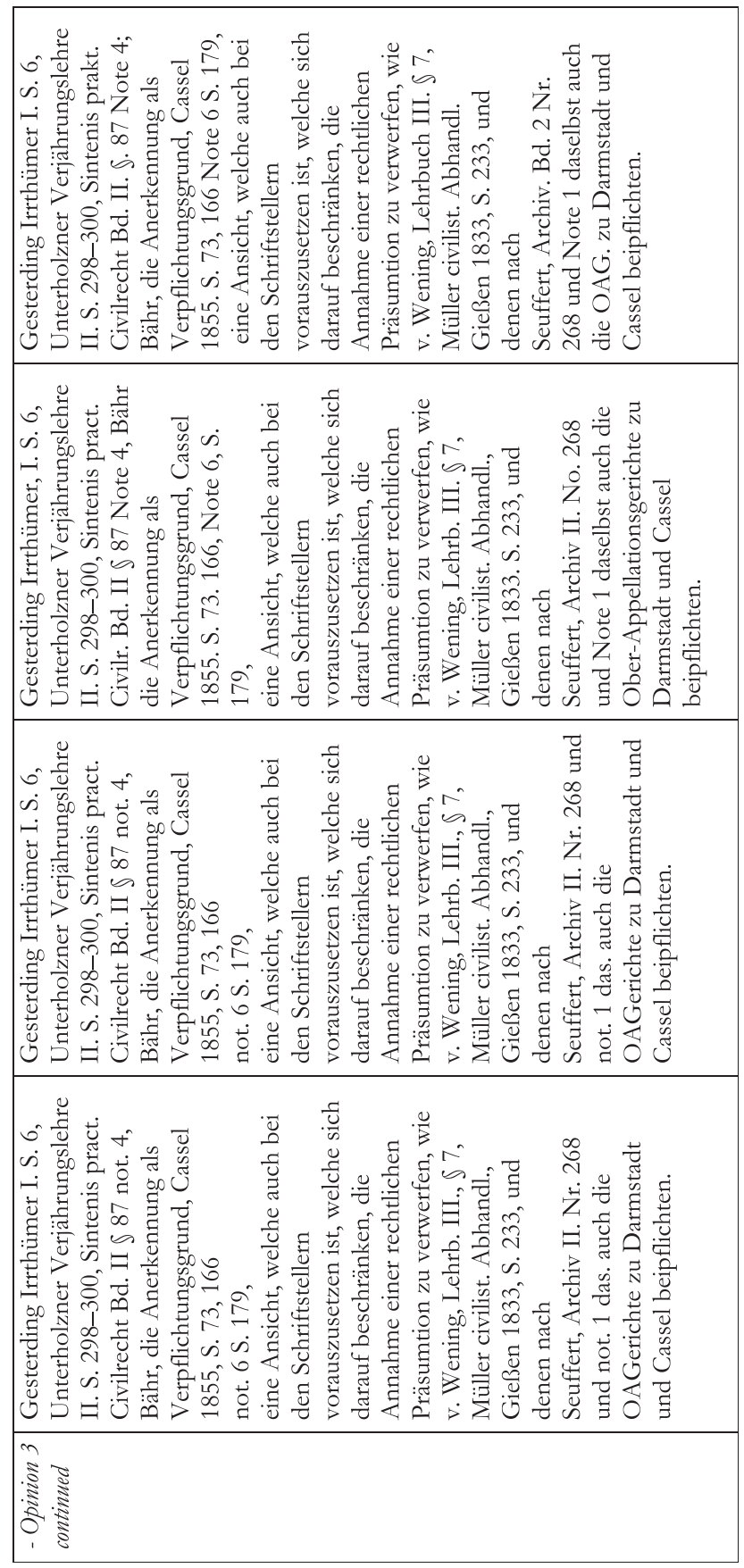

231 


\begin{tabular}{|c|c|}
\hline 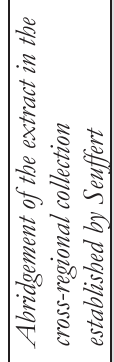 & 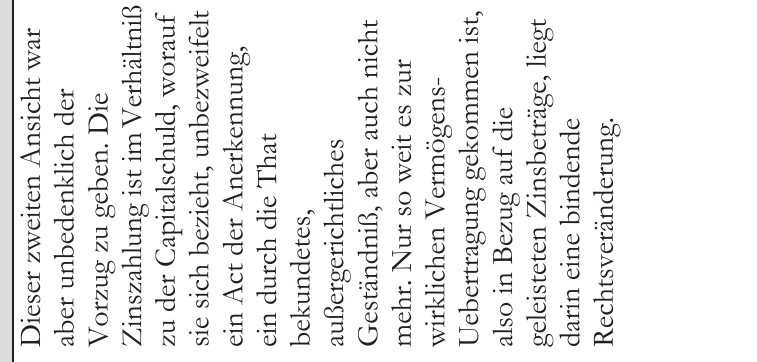 \\
\hline 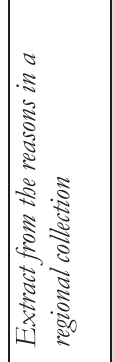 & 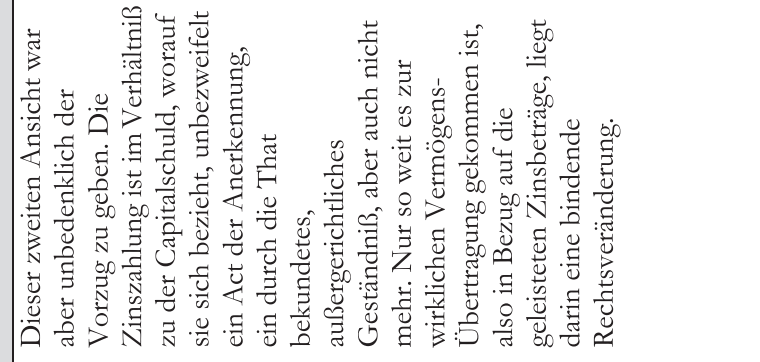 \\
\hline 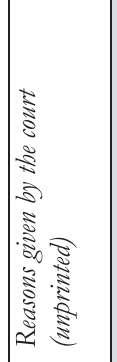 & 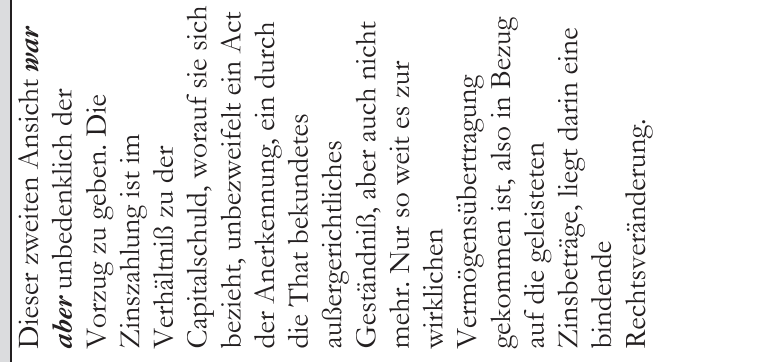 \\
\hline 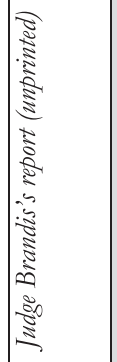 & 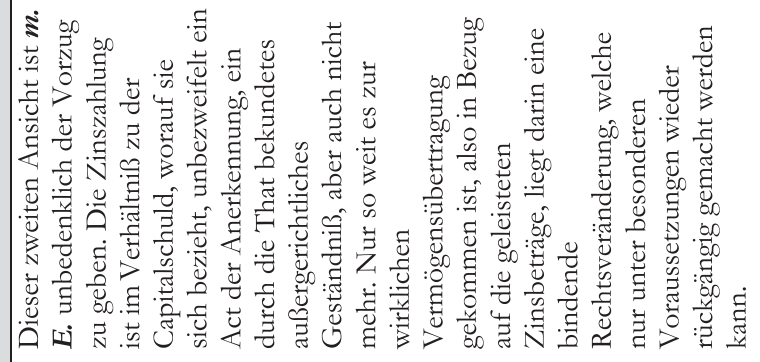 \\
\hline 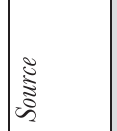 & \\
\hline
\end{tabular}

232 


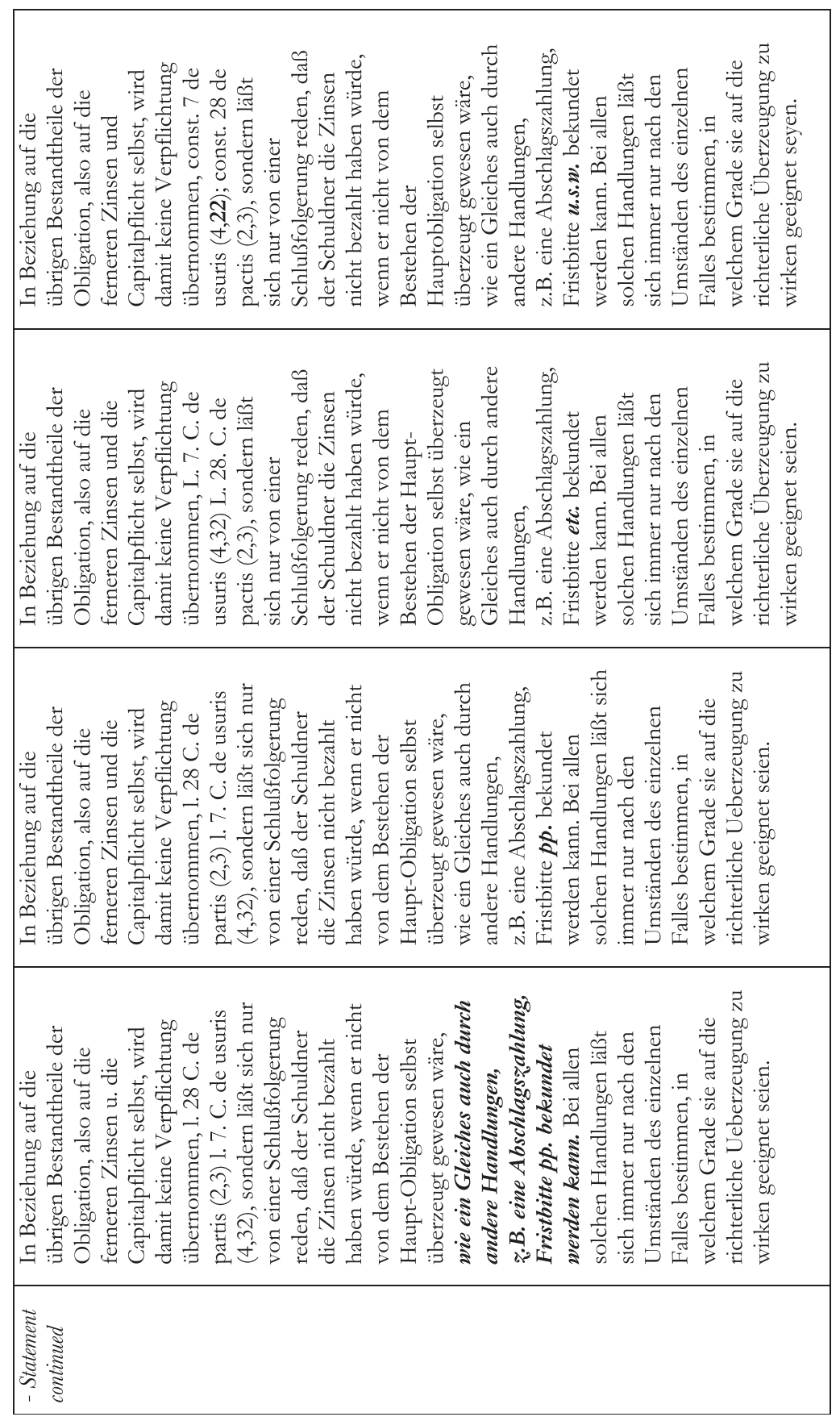




\begin{tabular}{|c|c|}
\hline 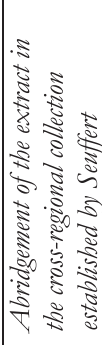 & 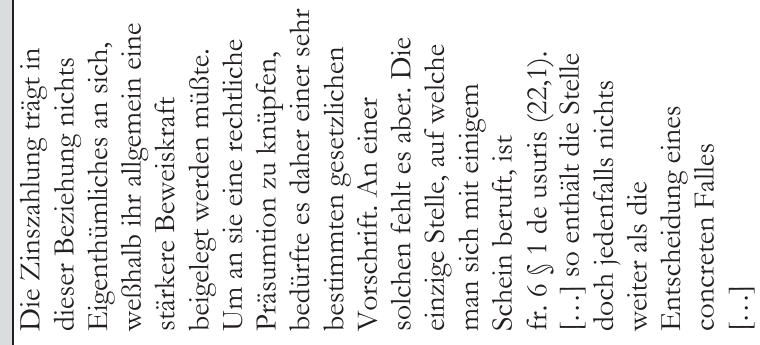 \\
\hline 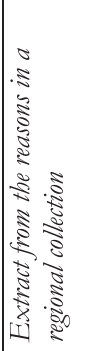 & 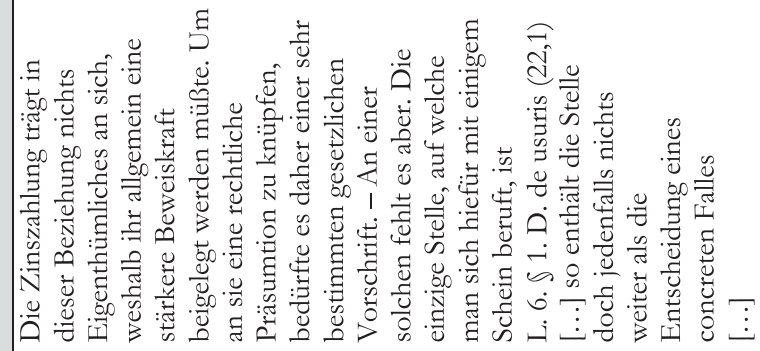 \\
\hline 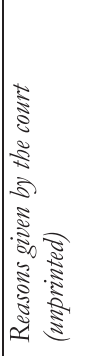 & 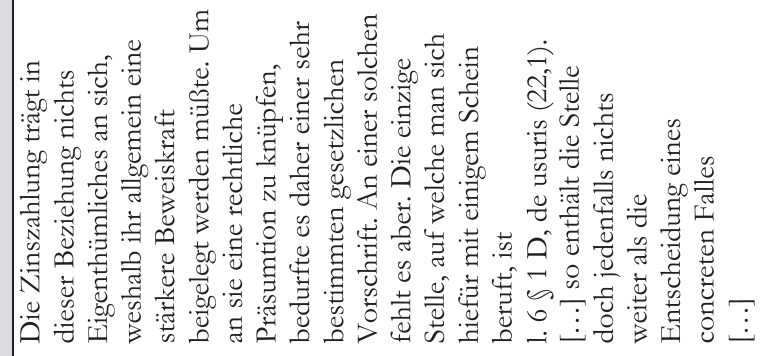 \\
\hline 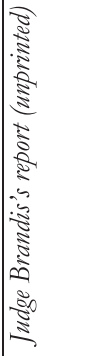 & 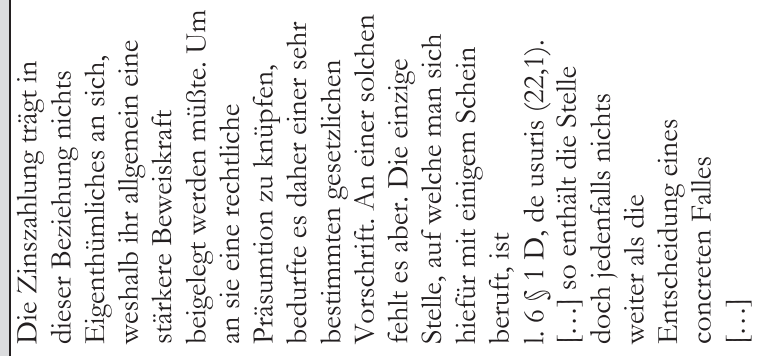 \\
\hline 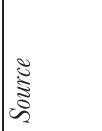 & 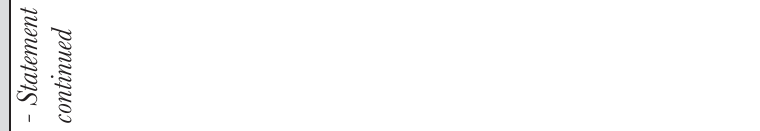 \\
\hline
\end{tabular}




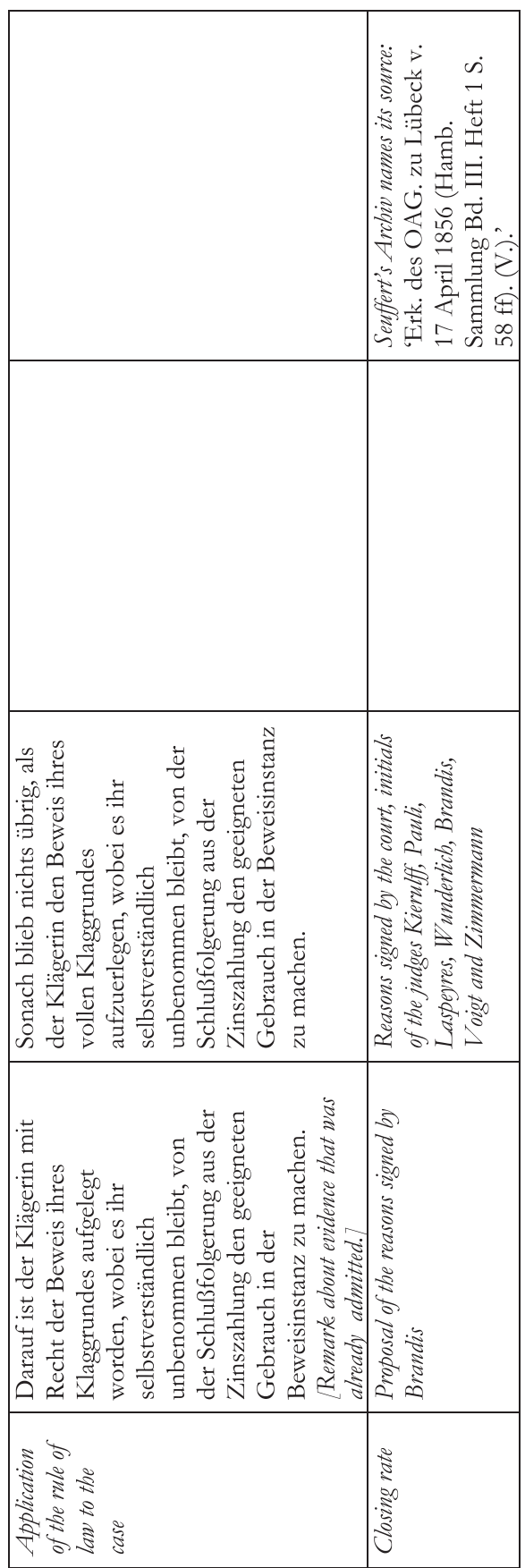

235 